\title{
A Study on the Rainfall and Landslides Along Sarawak Road Using the Antecedent Rainfall Analysis
}

\author{
Tay, J. E. ${ }^{1}$, Selaman, O. S. ${ }^{2}$
}

\begin{abstract}
Sarawak is a state known for its high percentage of clayey soil which is overlaid with "weak" strata. The state has experienced many cases of severe landslides which even resulted to deaths. This study aims to address the correlation between rainfall intensity and landslide occurrences along roads in Sarawak. By using the antecedent rainfall analysis, this study emphasizes on more than 50 cases of landslides which occurred along Sarawak roads in the early 2009. Where, during the month of January marks the most amount of rainfall experienced by the state in that year. Many landslide cases were reported, especially along the stretch of Sarawak roads, leading to injuries and road repair cost. The hyetograph drawn in this analysis provides probability of days of antecedent rainfall that induces landslides as well as the total amount of rainfall during the antecedent period that would lead to landslide occurrence. The intensity of rainfall on the day of landslides itself as well as the highest intensity of rainfall during the antecedent period is also analyzed to establish whether it is a factor leading to the landslide occurrence. The observations and forecasts present in this paper will provide warning system for the members of public as well as the state's civil defense authority before the occurrence of rainfall-induced landslide.
\end{abstract}

Keywords: Landslides, Antecedent Rainfall Analysis, Sarawak Roads, rainfall induced landslides, rainfall

\section{INTRODUCTION}

$\mathrm{M}$ alaysia is a country experiencing equatorial climate, which is high in humidity and high temperature throughout the year. The amount of rainfall in Malaysia is considered moderate as it seldom experiences severe drought. The average rainfall in Sarawak during the monsoon season had been recorded for the past few years and the maximum level of rainfall accumulated would be up to $700 \mathrm{~mm}$ a month. Rainfall is known to be one of the few main factors that triggers landslide. This study is about the rainfall and amount of precipitation accumulated in an hour, a day or a week before a landslide occurs along the road all over Sarawak.

Sarawak experiences the most rainfall among all the thirteen states in Malaysia. During the rainy season in Sarawak which is between the months of December to April every year, the rainfall data shows that the rain accumulated up to $600 \mathrm{~mm}$ (in the month of January) at its maximum while the minimum rainfall is $200 \mathrm{~mm}$ (in the month of June).

In the past five years, Sarawak suffered from 3 severe floods due to continuous rainfall, which was in year 2004, 2007 and as predicted, the year 2009. Heavy rainfall contributes highly to landslide cases along the roads in Sarawak, where most road landslide cases happened on hilly ground, while the lowland area suffers flooding. During the times of severe storm, the embankments along the roadsides are vulnerable to landslides. The landslides which occur on hilly area are mostly due to the continuous rainfall or heavy rainfall (intense storm) at a certain time. Continuous rainfall saturates the soil (with additional weight from the water content), thus weakening the hilly ground. The saturated soil strength decreases due to the increase in pore water pressure when the rainwater (contributed from heavy rainfall) penetrates into the soil. Any heavy loading vehicle which passes through the road weakens the soil even more thus causes the landslide to take place during that particular span of time.

\footnotetext{
${ }^{1}$ Undergraduate, Faculty of Engineering, UNIMAS. (email: julietkathleen@yahoo.com)

${ }^{2}$ Lecturer, Department of Civil Engineering, Faculty of Engineering, UNIMAS. (email: sosuhaiza@feng.unimas.my)
} 
Among the recent landslide cases which happened in the early year 2009 was at KM 45, Bintulu-Tatau road. From the 'Online News Article', (21 January 2009) titled Landslide Cuts Off Major Sarawak Road Link, the landslide which occurred at 5.10 am on January $21^{\text {st }} 2009$ caused road users to double back from where they came from. The Bintulu-Tatau road was the only road connecting Miri-Kuching. A concrete mixer truck fell into the ditch at the landslide location.

This research focuses on how rainfall contributes to landslides along the federal road in Sarawak. This study is to provide a proper data collection for civil defense department to create real time warning for road users before the actual occurrences of landslides. Historical landslide events along Sarawak roads as well as the rainfall that contribute to the landslides will be collected and then observed. This is to enable the observation between the rainfalls at that particular time of the landslide at the area. This research covers the federal road in Sarawak which stretches all along Sarawak from Kuching division to Limbang division during the rainy season in the year 2009 between the months of January to May.

\section{RESEARCH MATERIALS USED AND ALAYSIS PROCEDURES}

\section{A. Landslides information}

The areas of landslide along Sarawak roads are procured from Jabatan Kerja Raya, JKR road maintenance department in Headquarters and JKR website e-bencana alam: tanah runtuh. The landslide information includes the time, date, areas of slide as well as size of the landslides. Geosciences and Meteorological Department Kuching had also kept information on historical landslide areas. Pictures of landslides are obtained from the reports to observe the types of landslide (whether shallow, translational or deep seated landslides).Rainfall data for each of the landslide areas, based on the dates given, were collected on monthly basis from Drainaga and Irrigation Department Sarawak.

\section{B. Data Classification}

The data for rainfall and landslides are classified into:

I.Rainfall distribution- the rainfall distribution in Sarawak and its pattern based on the daily and monthly rainfall data.

II.Landslides in Sarawak-each landslide in Sarawak are classified based on the types, shallow landslide, translational landslide, deep-seated landslide, shallow translational landslide and etc.

III. The frequency of rainfall and types of rainfall is recorded and determined to see which of those that are the common rainfall (intense storm, cumulative antecedent rainfall) that triggers rainfall-induced landslide.

\section{Method of Analysis}

The correlation of rainfall and landslide is analysed to see how the amount, type and areas of rainfall affects the weak soil and causes landslides along the roads in Sarawak.

Method of landslide analysis consist of types of landslide analysis used by various researches and from these methods, the analysis for antecedent rainfall is used to analyze the landslide-induced rainfall in Sarawak. The antecedent rainfall method was chosen as it has been a common analysis done in regions with equatorial monsoon rain as experienced in Sarawak. The cumulative daily rainfall affects the landslide occurrences along the roads in Sarawak.

The details of landslides, including the location and time of each landslide which occurred along Sarawak road are tabulated in Table 1.

TABLE 1

LANDSLIDE OCCURRENCE ALONG THE ROAD IN SARAWAK

\begin{tabular}{|r|l|l|l|l|}
\hline No & Location of landslide & Sections & $\begin{array}{l}\text { Division / } \\
\text { District }\end{array}$ & Time of slide \\
\hline 1 & Jalan Muara Mongkos & KM3,KM5 \& KM7 & Samarahan & $14 / 01 / 2009[10.00 \mathrm{PM}]$ \\
\hline 2 & Jalan Kpg Tema & KM1+000 & Samarahan & $19 / 01 / 2009[8.00 \mathrm{AM}]$ \\
\hline 3 & Jalan Muara Mongkos & KM7+500 & Kuching & $11 / 01 / 2009[8.00 \mathrm{AM}]$ \\
\hline 4 & Jalan Muara Mongkos & KM7+500 & Kuching & $11 / 01 / 2009[8.00 \mathrm{AM}]$ \\
\hline 5 & Jalan Pejiru/Padang Pan/Gumbang & KM11+500-11+540 & Bau & $12 / 01 / 2009[1.00 \mathrm{AM}]$ \\
\hline 6 & Jalan Pejiru/Padang Pan/Gumbang & KM10+700-10+730 & Bau & $12 / 01 / 2009[1.00 \mathrm{AM}]$ \\
\hline 7 & Jalan Pejiru/Padang Pan/Gumbang & KM9+900-KM10+00 & Bau & $12 / 01 / 2009[1.00 \mathrm{AM}]$ \\
\hline 8 & Jalan Serian-Tebedu & KM26+900 & Samarahan & $19 / 01 / 2009[8.00 \mathrm{AM}]$ \\
\hline 9 & Jalan Pusa Spur & KM2+600 & Saribas & $11 / 01 / 2009[12.30 \mathrm{pm}]$ \\
\hline 10 & Jalan Kepayang/Kedumpai & KM8+300 & Serian & $12 / 01 / 2009[2.00 \mathrm{AM}]$ \\
\hline
\end{tabular}




\section{Rainfall Data}

The rainfall stations located near to the landslide areas are determined according to the Sarawak Hydrological yearbook rainfall stations map in each river basin. The heavy rainfall during the previous month contributes to high moisture in the soil (saturates the soil) and decreases the soil strength, thus leading to landslide occurrence. Table 2 is the rainfall data of 11 days before the day of landslide collected from the stations that are near landslides area.

TABLE 2

11 DAYS ANTECEDENT RAINFALL FOR EACH LANDSLIDE AREA

\begin{tabular}{|c|c|c|c|c|c|c|c|c|c|c|c|c|}
\hline $\begin{array}{l}\text { Areas of } \\
\text { landslide }\end{array}$ & \multicolumn{12}{|c|}{$\begin{array}{c}\text { Date (in year 2009) \& } \\
\text { Rainfall amount (in } \mathrm{mm} \text { ) }\end{array}$} \\
\hline \multirow{2}{*}{$\begin{array}{l}\text { Bunan } \\
\text { Gega }\end{array}$} & Date & $4 / 1$ & $5 / 1$ & $6 / 1$ & $7 / 1$ & $8 / 1$ & $9 / 1$ & $10 / 1$ & $11 / 1$ & $12 / 1$ & $13 / 1$ & $14 / 1$ \\
\hline & Rainfall & 6 & 69 & 3 & 51 & 10 & 13 & 123 & 45 & 0 & 2 & 1 \\
\hline \multirow{2}{*}{$\begin{array}{l}\text { Tebedu } \\
\text { Case } 1\end{array}$} & Date & $9 / 1$ & $10 / 1$ & $11 / 1$ & $12 / 1$ & $13 / 1$ & $14 / 1$ & $15 / 1$ & $16 / 1$ & $17 / 1$ & $18 / 1$ & $19 / 1$ \\
\hline & Rainfall & 9 & 109 & 70 & 0 & 2 & 4 & 6 & 14 & 3 & 1 & 0 \\
\hline \multirow{2}{*}{$\begin{array}{l}\text { Tebedu } \\
\text { Case } 2\end{array}$} & Date & $6 / 1$ & $7 / 1$ & $8 / 1$ & $9 / 1$ & $10 / 1$ & $11 / 1$ & $12 / 1$ & $13 / 1$ & $14 / 1$ & $15 / 1$ & $16 / 1$ \\
\hline & Rainfall & 1 & 62 & 41 & 9 & 109 & 70 & 0 & 2 & 4 & 6 & 14 \\
\hline \multirow{2}{*}{$\begin{array}{c}\text { Kpg } \\
\text { Sagah }\end{array}$} & Date & $1 / 1$ & $2 / 1$ & $3 / 1$ & $4 / 1$ & $5 / 1$ & $6 / 1$ & $7 / 1$ & $8 / 1$ & $9 / 1$ & $10 / 1$ & $11 / 1$ \\
\hline & Rainfall & 21 & 2 & 11 & 2 & 5 & 4 & 42 & 64 & 70 & 208 & 288 \\
\hline \multirow[t]{2}{*}{ Bau } & Date & $2 / 1$ & $3 / 1$ & $4 / 1$ & $5 / 1$ & $6 / 1$ & $7 / 1$ & $8 / 1$ & $9 / 1$ & $10 / 1$ & $11 / 1$ & $12 / 1$ \\
\hline & Rainfall & 1 & 5 & 1 & 30 & 18 & 43 & 106 & 66 & 374 & 214 & 0 \\
\hline \multirow[t]{2}{*}{ Tatau } & Date & $10 / 1$ & $11 / 1$ & $12 / 1$ & $13 / 1$ & $14 / 1$ & $15 / 1$ & $16 / 1$ & $17 / 1$ & $18 / 1$ & $19 / 1$ & $20 / 1$ \\
\hline & Rainfall & 143.5 & 49 & 44.5 & 15 & 64 & 55.5 & 8.5 & 94 & 172 & 13.5 & 85.5 \\
\hline \multirow{2}{*}{$\begin{array}{c}\text { Sebauh } \\
\text { case } 1\end{array}$} & Date & $4 / 1$ & $5 / 1$ & $6 / 1$ & $7 / 1$ & $8 / 1$ & $9 / 1$ & $10 / 1$ & $11 / 1$ & $12 / 1$ & $13 / 1$ & $14 / 1$ \\
\hline & Rainfall & 20 & 10.5 & 5.5 & 39.5 & 16 & 52.5 & 3.5 & 48.5 & 29.5 & 18 & 31 \\
\hline \multirow{2}{*}{$\begin{array}{c}\text { Sebauh } \\
\text { Case } 2\end{array}$} & Date & $11 / 1$ & $12 / 1$ & $13 / 1$ & $14 / 1$ & $15 / 1$ & $16 / 1$ & $17 / 1$ & $18 / 1$ & $19 / 1$ & $20 /$ & $21 / 1$ \\
\hline & Rainfall & 48.5 & 29.5 & 18 & 31 & 20 & 0.5 & 2 & 6.5 & 17 & 97.5 & 1 \\
\hline \multirow[t]{2}{*}{ Bekenu } & Date & $28 / 1$ & $29 / 1$ & $30 / 1$ & $31 / 1$ & $1 / 2$ & $2 / 2$ & $3 / 2$ & $4 / 2$ & $5 / 2$ & $6 / 2$ & $7 / 2$ \\
\hline & Rainfall & 9.5 & 127.5 & 93.5 & 96.5 & 2.5 & 5.5 & 21.5 & 2.5 & 73.5 & 1 & 0 \\
\hline \multirow{2}{*}{$\begin{array}{c}\text { Saratok } \\
\text { DID }\end{array}$} & Date & $1 / 1$ & $2 / 1$ & $3 / 1$ & $4 / 1$ & $5 / 1$ & $6 / 1$ & $7 / 1$ & $8 / 1$ & $9 / 1$ & $10 / 1$ & $11 / 1$ \\
\hline & Rainfall & 28 & 10 & 14 & 6 & 51.5 & 2.5 & 21 & 47.5 & 20.5 & 120 & 57.5 \\
\hline \multirow[t]{2}{*}{ Pusa } & Date & $1 / 1$ & $2 / 1$ & $3 / 1$ & $4 / 1$ & $5 / 1$ & $6 / 1$ & $7 / 1$ & $8 / 1$ & $9 / 1$ & $10 / 1$ & $11 / 1$ \\
\hline & Rainfall & 23 & 34 & 28 & 6 & 3 & 3 & 3.5 & 82 & 50.5 & 173.5 & 112 \\
\hline \multirow[t]{2}{*}{ Marudi } & Date & $10 / 1$ & $11 / 1$ & $12 / 1$ & $13 / 1$ & $14 / 1$ & $15 / 1$ & $16 / 1$ & $17 / 1$ & $18 / 1$ & $19 / 1$ & $20 / 1$ \\
\hline & Rainfall & 42 & 2.5 & 26 & 15.5 & 0 & 23 & 0.5 & 0.5 & 1.5 & 4 & 83.5 \\
\hline \multirow[t]{2}{*}{ Padawan } & Date & $1 / 1$ & $2 / 1$ & $3 / 1$ & $4 / 1$ & $5 / 1$ & $6 / 1$ & $7 / 1$ & $8 / 1$ & $9 / 1$ & $10 / 1$ & $11 / 1$ \\
\hline & Rainfall & 0 & 8 & 1 & 0 & 26 & 3 & 66 & 31 & 21 & 131 & 71 \\
\hline \multirow[t]{2}{*}{ Serian } & Date & $6 / 1$ & $7 / 1$ & $8 / 1$ & $9 / 1$ & $10 / 1$ & $11 / 1$ & $12 / 1$ & & & & \\
\hline & Rainfall & 29 & 85 & 8 & 15 & 215 & 53 & 27 & & & & \\
\hline \multirow{2}{*}{$\begin{array}{c}\text { Miri } \\
\text { Airport }\end{array}$} & Date & $19 / 1$ & $20 / 1$ & $21 / 1$ & $22 / 1$ & $23 / 1$ & $24 / 1$ & $25 / 1$ & $26 / 1$ & $27 / 1$ & $28 / 1$ & $29 / 1$ \\
\hline & Rainfall & 125.5 & 37 & 0.5 & 1 & 0.5 & 34 & 41 & 21 & 5.5 & 52 & 89 \\
\hline \multirow[t]{2}{*}{ Debak } & Date & $1 / 1$ & $2 / 1$ & $3 / 1$ & $4 / 1$ & $5 / 1$ & $6 / 1$ & $7 / 1$ & $8 / 1$ & $9 / 1$ & $10 / 1$ & $11 / 1$ \\
\hline & Rainfall & 21 & 19 & 27 & 8 & 12.5 & 26 & 22 & 71.5 & 23 & 129.5 & 23 \\
\hline
\end{tabular}

\section{RESULTS AND DISCUSSION}

\section{A. Hyetograph of rainfall stations}

The hyetograph is plotted using the daily rainfall data at the rainfall stations close to the landslide area. The amount of rainfall in 11 days before the day of landslide is plotted against time. The cumulative value of rainfall is included in the graph and that makes the outcome of the antecedent days of rainfall hyetograph. The last day on the graph marks the day of landslide occurrence at the area near the selected stations. Antecedent period is the consecutive days with or without rainfall, before the day of landslide. 


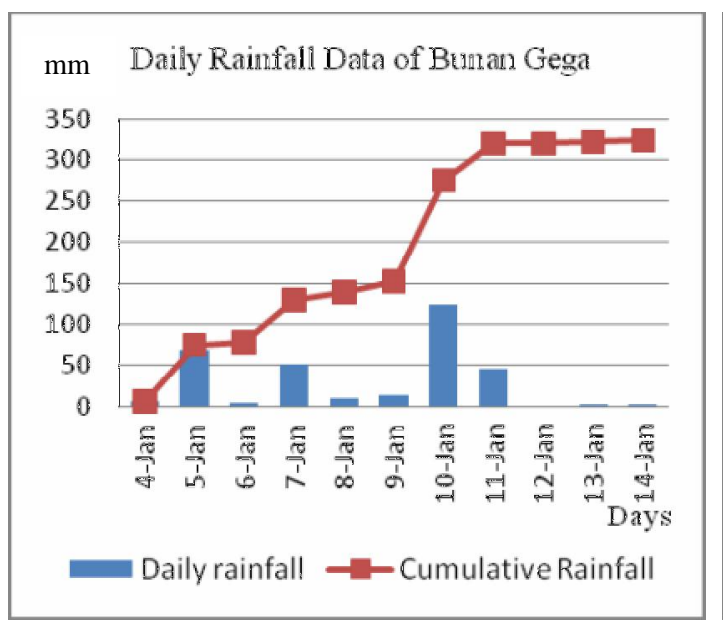

Figure 1 Hyetograph (11 day) of Bunan Gega

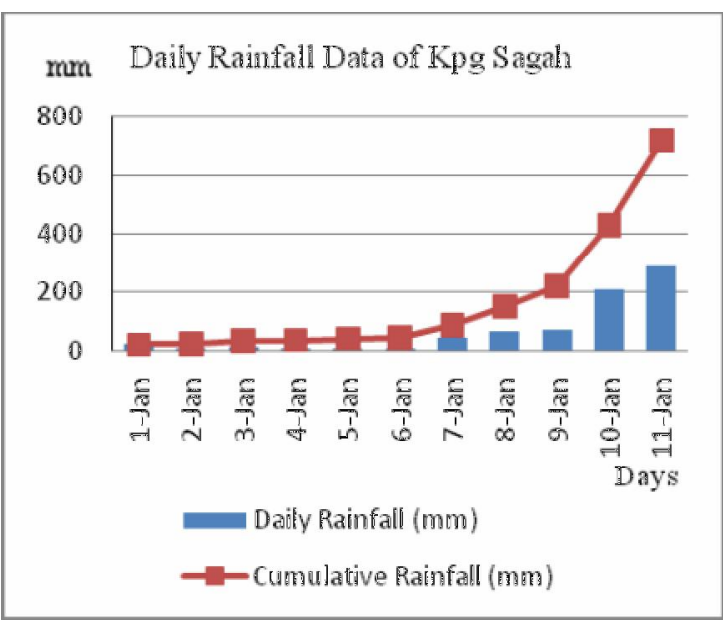

Figure 2 Hyetograph (11 day) of Kpg Sagah

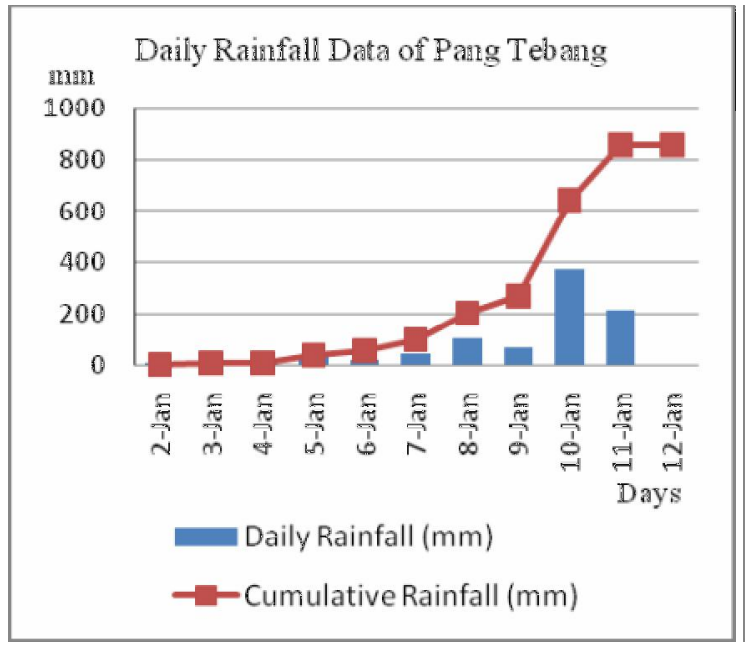

Figure 3 Hyetograph (11 day) of Pang Tebang

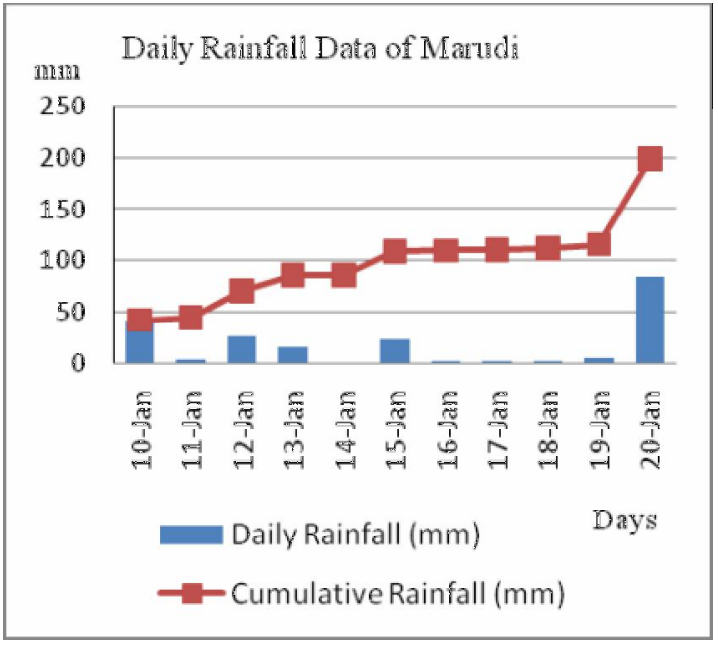

Figure 4 Hyetograph (11 day) of Marudi

From 16 graphs of the rainfall stations, most of the cumulative rainfall shows constant rise. This means that within those 11 days of antecedent rainfall, almost every day has rainfall. The continuous rainfall could be the factor that leads to slope instability that accumulates to the day of landslide (Fuhrmann et al., 2002; Chowdhury \& Flentje, 2002; Okada et al., 2007; Sivrikaya et al., 2007; Guzzetti et al., 2007; Ahrendt \& Valentin Zuquette, 2003; Pedrozzi, 2004; Nagarajan et al., 2000; Mihalić et al., 2009; Japzon, 2006).

The purpose of the graph is to observe the pattern of rainfall, while the tables of daily rainfall data give the exact amount of rainfall at the stated area. From the Figures, it shows that out of 16 rainfall stations, 11 station shows that there was at least a day of heavy rainfall of more than $100 \mathrm{~mm}$ in the 11 days of antecedent rainfall. In Figure 3 (Daily rainfall hyetograph of Pang Tebang), the maximum daily rainfall was $374 \mathrm{~mm}$ which occurred approximately 2 days before the landslides. This is known as the maximum rainfall threshold that initiates the landslides (Guzzetti et al., 2007), where the magnitude of rainfall before the initiation of landslide is considered. In the period of antecedent rainfall of 11 days, there will be at least a day of heavy rainfall within those 11 days. That could be the trigger that leads to slope failure before the real landslide really occurs on the $11^{\text {th }}$ day of antecedent rainfall period.

\section{B. Antecedent Rainfall Analysis}

In order to determine the rainfall threshold at the landslide area, this study uses an analysis where a cumulative rainfall for 11 days with an increment or peak of rainfall at certain volume (millimeter) is collected. The minimum amount of rainfall in 11 days of antecedent rainfall that could trigger landslide is $300 \mathrm{~mm}$. 


\section{Intense Storm}

Intense storm is the occurrence of high frequency rainfall also known as heavy rainfall at a very short and continuous period of time. This occurrence of intense storm could exist during the period of antecedent rainfall. Although this study delve into antecedent rainfall analysis, but there are times, that during the antecedent rainfall, there will be a day when rainfall is very intense for a few hours, thus, this study also look into the correlation between heavy rainfall and landslide occurrence.For determining the intense hourly storm, a certain area of analysis with this pattern of rainfall (intense storm) is selected in hourly rainfall basis.

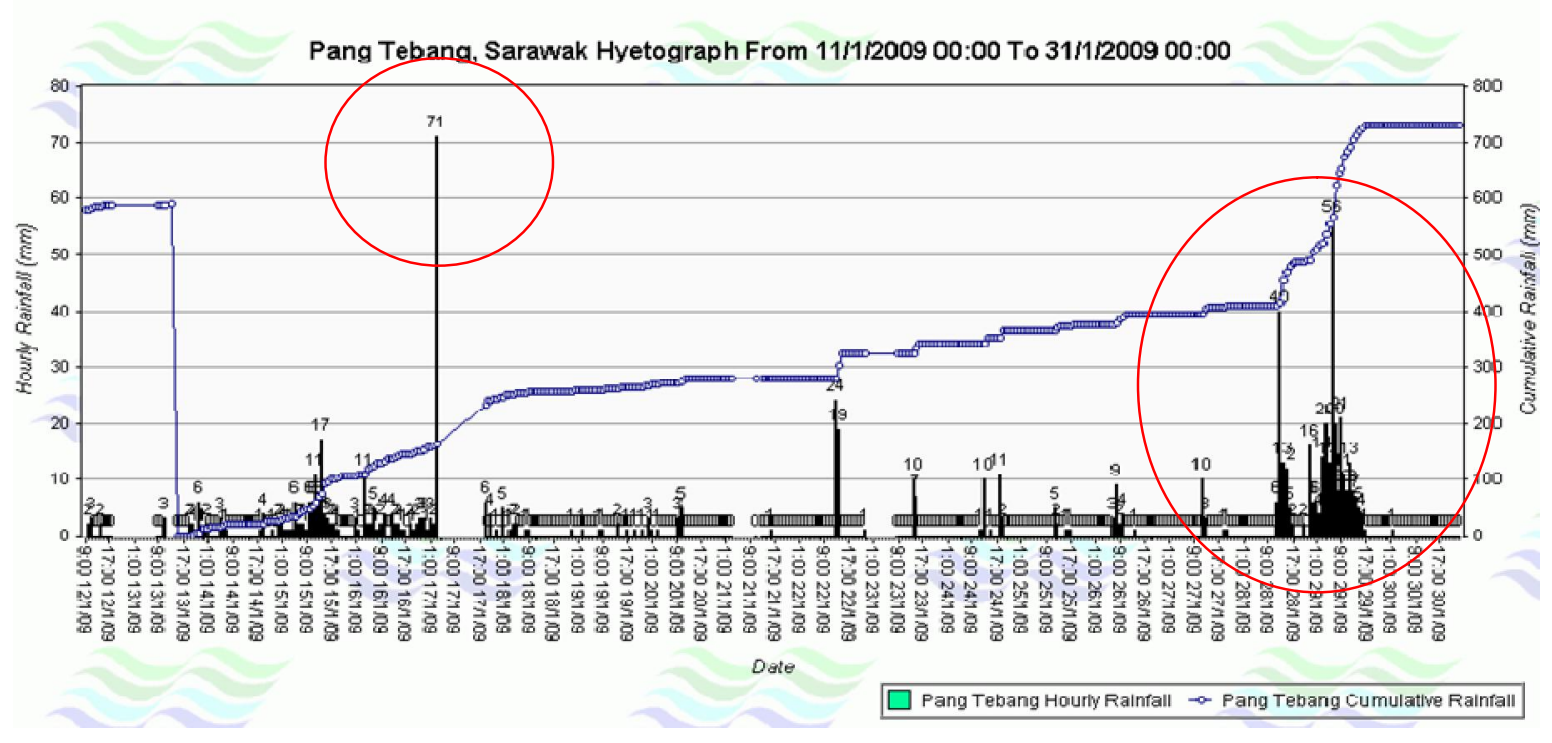

Figure 5 Hourly Rainfall Hyetograph

During the antecedent rainfall period in this analysis, there are five cases observed to have intense storm within the 11 days of antecedent rainfall. The five cases are Tebedu, Bunan Gega, Bau, Padawan,and Pang Tebang. Out of the 5 intense rainfall cases (with high magnitude rainfall intensity), it is shown that the high intensity rainfall does not contribute to the immediate landslide and the major reasons for landslide occurrence along Sarawak road are mainly antecedent rainfall itself. Intense storm do not lead to immediate occurrence of landslide, but if there are occurrence of intense storm in the antecedent rainfall period, it is a trigger for the landslide occurrence. Based on Figure 5 above, reports of landslides in Pang Tebang, Bau district, there were no landslide occurrences during that period of intense storm as marked in the figure.

\section{CONCLUSIONS}

This rainfall pattern falls under the classification of continuous daily rainfall. As observed from most of the figures above, Sarawak usually experiences consecutive rainfall at a certain period of time. Although the rainfall was continuous, it was still heavy because mostly exceeds $100 \mathrm{~mm}$ of daily rainfall. This is one of the reasons why landslides easily occur in Sarawak during the monsoon period of 2009.

It is proven that the landslide occurrences along Sarawak roads can be correlated with the patterns of rainfall and are proportional with the amount of rainfall accumulated, especially continuous rainfall in the antecedent period of 11 days. When the monthly rainfall exceeds $500 \mathrm{~mm}$, it is likely for landslide to occur in that month or the consecutive month, depending on the daily rainfall distribution as well as the site condition. Since most Sarawak roads are located at hilly areas, the site condition enables shallow rapid landslide or shallow translational landslide (on curvy roads with hills or valley) to occur.

\section{ACKNOWLEDGEMENT}

The authors would like to thank JKR Road Maintenance Department Kuching, Drainage and Irrigation Department (Kota Samarahan), and Geosciences and Mineralogy Department for providing informations needed for the research. 


\section{REFERENCES}

[1] Ahmad, R., Miller, D. J., Rowe, D. C., (2009). Landslide Related To Precipitation In Eastern Jamaica.

[2] Ahrendt, A.,\& Zuquette, L. V. (2003). Triggering factors of landslides in Campos do Jorda o city, Brazil. Bull Engineering Geology Environment, 62, pp, 231-244.

[3] Bardet J. P. (2004), November 2,2004 Field reconnaissance of the Niigata-Ken Chuesetsu earthquake of October 3, 2004.

[4] Brunetti, M. T., Peruccacci, S., Rossi, M., Guzzetti, F., Reichenbach, P., Ardizzone, F., Cardinali, M., Mondini, A., \& Salvati, P., Tonelli, G., Valigi D, \& Luciani, S. (2009). A prototype system to forecast rainfall induced landslides in Italy.

[5] Cardinalli M., Galli M., Guzzetti F., Ardizzone F., Reichenbachi P., and Bartoccini P. (2006). Rainfall induced landslides in December 2004 in south-western Umbria, central Italy: types, extent, damage and risk assessment, Natural Hazards Earth System, 6, pp 237 260.

[6] Christanto, N., Hadmoko, D. S., Westen, C. J., Lavigne, F., Sartohadi, J.,\& Setiawan, M. A. (2009). Characteristic and Behavior of Rainfall Induced Landslides in Java Island, Indonesia : an Overview. Geophysical Research Abstracts, Vol. 11,

[7] Chowdhury R. \& Flentje P. (2002). Uncertainties in rainfall-induced landslide hazard. Quarterly Journal of Engineering Geology and Hydrogeology, 35, pp, 61-70.

[8] Fuhrmann, C. M., Konrad, C, E. II, \& Band, L., E. (2008). Climatological Perspectives On the rainfall characteristics associated with landslides in Western Carolina. Physical Geography, 29 (4), pp, 289-305.

[9] Glade T., Crozier M., \& Smith P., (2000). Applying Probability Determination to Refine Landslide-triggering Rainfall Thresholds Using an Empirical “Antecedent Daily Rainfall Model”. Pure appl. geophys. 157, pp, 1059-1079.

[10] Guzzetti, F., Peruccacci, S., Rossi, M., \& Stark, C. P. (2007). Rainfall thresholds for the initiation of landslide in central and southern Europe. Meteorol Atmos Phys , 98,pp, 239-267.

[11] Guzzetti, F., Stark, C. P., Salvati P. (2005). Evaluation of Flood and Landslide Risk to the Population of Italy. Environmental Management 36 (1),pp, 155-36.

[12] Hearn, G., Hunt,T., Aubert, J. \& Howell,J. (2007). Landslide impacts on the road network of Lao PDR and the feasibility of implementing a slope management programme. Ground Engineering, p, 22

[13] Hong Y., Adler R. F., Negri A., \& Huffman G. J. (2007). Flood and landslide applications of near real-time satellite rainfall products. Natural Hazards, 43, pp, 285-294.

[14] Japzon, M. (2006). Rainfall, Quake Triggered Leyte Landslide, Bulatlat, vol 6, no 3.

[15] Lam S. K. (1998). M ap Report 9, Quatenery Geology of The Kuching Area, Sarawak: Geological Survey Department Malaysia

[16] Lee, S., \& Talib, J. A. (2005). Probabilistic landslide susceptibility and factor effect analysis. Environment Geology, 47, pp, 982-990.

[17] Mihalić, S., Žugaj, R., \& Jurak, V. (2009). The Influence of Heavy Rainfall on the Landslide Initiation.

[18] Nagarajan R., Roy A., Vinod K. Mukherjee, A., \& Khire, M.,V. (2000). Landslide hazard susceptibility mapping based on terrain and climatic factors for tropical monsoon regions. Bull Eng Geol Env, 58, pp, 275-287.

[19] Okada ,Y., Ochiai, H., Okamoto, T., Sassa, K., Fukuoka, H., Igwe, O. (2007). A complex earth slide-earth flow induction by the heavy rainfall in July 2006, Okaya City, Nagano prefecture, Japan. Landslides (2007) 4, pp, 197-203.

[20] Ozdemir, A. (2008). Landslide susceptibility mapping of vicinity of Yaka Landslide (Gelendost, Turkey) using conditional probability approach in GIS. Environ Geol, 57, pp,1675-1686.

[21] Rahardjo, H., Li, X.W., Toll, D. G., \& Leong, E. C. (2001). The effect of antecedent rainfall on slope stability. Geotechnical and Geological Engineering 19: 371-399, 2001.

[22] Rotaru, Oajdea, D., \& Răileanu, P. (2007). Analysis of the Landslide M ovements. International J ournal of Geology. 3 vol. 1, pp, 70-79

[23] Pedrozzi, G. (2004). Triggering of landslides in Canton Ticino (Switzerland) and prediction by the rainfall intensity and duration method. Bull Engineering Geology Environment, 63, pp 281-291.

[24] Sidle, R. (2005). "Influence of forest harvesting activities on debris avalanches and flows," Debris-flow Hazards and Related Phenomena. Springer, pp. 387-409.

[25] Sidle, R.C., \& Ochiai, H., (2006). Landslides: Processes, prediction, and land use. Water Resour. Monogr. 18

[26] Sivrikaya, O., Kilic A. M., Yalcin, M. G., Aykamis ,A. S. , Sonmez, M. (2008). The 2001 Adana landslide and its destructive effects.Turkey. Environ Geol, 54, pp1489-1500 